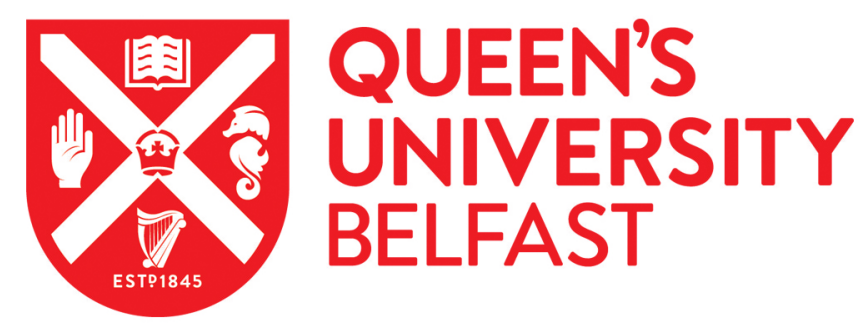

\title{
'This is a beautiful school.' 'This school is useless!' Explaining disengagement in a Greek vocational school through the examination of teacher ideologies
}

Giannakaki, M-S., \& Batziakas, G. (2016). 'This is a beautiful school.' 'This school is useless!' Explaining disengagement in a Greek vocational school through the examination of teacher ideologies. Research in PostCompulsory Education, 21(4), 409-433. https://doi.org/10.1080/13596748.2016.1226585

Published in:

Research in Post-Compulsory Education

Document Version:

Peer reviewed version

Queen's University Belfast - Research Portal:

Link to publication record in Queen's University Belfast Research Portal

\section{Publisher rights}

This is an Accepted Manuscript of an article published by Taylor \& Francis in Research in Post-Compulsory Education on 26th Oct 2016, available online: http://www.tandfonline.com/10.1080/13596748.2016.1226585

\section{General rights}

Copyright for the publications made accessible via the Queen's University Belfast Research Portal is retained by the author(s) and / or other copyright owners and it is a condition of accessing these publications that users recognise and abide by the legal requirements associated with these rights.

Take down policy

The Research Portal is Queen's institutional repository that provides access to Queen's research output. Every effort has been made to ensure that content in the Research Portal does not infringe any person's rights, or applicable UK laws. If you discover content in the

Research Portal that you believe breaches copyright or violates any law, please contact openaccess@qub.ac.uk. 


\section{'This is a beautiful school.' 'This school is useless!!' Explaining disengagement in a Greek vocational school through the examination of teacher ideologies}

Marina-Stefania Giannakaki ${ }^{a^{*}}$, Georgios Batziakas ${ }^{b}$

a School of Education, Queen's University Belfast, 20 College Green, Belfast BT71LN, UK; email: m.giannakaki@qub.ac.uk; tel.+44 (0)2890975997.

${ }^{b}$ Department of Primary Education, University of Thessaly. Argonafton \& Filellinon, Volos 38321, Greece; email: georbatz@gmail.com; tel.+302421050922.

*Corresponding author.

Marina-Stefania Giannakaki is a Lecturer in Educational Leadership at the School of Education of Queen's University Belfast, where she coordinates the MSc Educational Leadership course. Her research interests are in culturally responsive, humanistic forms of leadership, as well as in leading cultural change, in educational organisations.

Georgios Batziakas is a secondary school teacher in Greece and holds an MSc in Educational Organisation and Management from the University of Thessaly. He has 21 years of teaching experience and has undertaken key leadership roles in various educational establishments.

\section{Acknowledgements}

We are grateful to Professor Allen Thurston for his helpful comments on conceptual and methodological aspects of earlier drafts of this paper. Thanks are also due to Mr. Leslie S. Woodcock for his comments on the English text. 


\section{'This is a beautiful school.' 'This school is useless!!' Explaining disengagement in a Greek vocational school through the examination of teacher ideologies}

This multimethod case study of a Greek vocational school explored teachers' culture (including beliefs about education, teachers' role, and students' nature) using the concept of Pupil Control Ideology to explain problems of disengagement and low morale among staff and students, as well as tensions in relationships. A prominent custodial culture was identified in the school using a functional/apolitical pedagogy to transmit 'legitimate' knowledge to students whose working-class background did not produce desired outcomes. This generated deficit views of students, teachers' sympathy, and a seemingly caring school ethos which was, nevertheless, oppressive. Students' failings were naturalised and vocational education misinterpreted as merely a streaming device in a system honouring academic achievement and middle-class ways. Teachers were blind to these cultural subtleties, believing they acted 'rationally' and altruistically. A humanistic subculture emphasising student empowerment and social transformation consisted of a minority of teachers and was rather marginalised. This disallowed meaningful dialogue and the identification of an alternative rationale for the sector, generating strong feelings of futility. Positive change in this school necessitated the deconstruction and (subsequent) reconstruction of custodial teachers' worldview as embedded in their practice.

Keywords: educational beliefs; pupil control ideology; vocational education; teachers; school culture; leadership. 


\section{Introduction}

This paper reports on a case study of teachers’ culture in a Greek vocational uppersecondary school (post-compulsory education) aiming to explain disengagement, low morale, and tense relationships among staff and students. Such problems exist at large scale in school-based vocational education in Greece and are associated with low student attainment and high drop-out rates in the sector, rendering this type of education unattractive to families who, in their majority, prefer to send their children to academically-oriented schools (Paidousi 2016). These problems exist even though vocational schools (known as Vocational Lyceums) are officially ${ }^{1}$ assigned equal status to the academically-oriented General Lyceums, employ teachers with same-level qualifications and pedagogical training (Level 6 or higher) ${ }^{2}$, and provide access to Higher Education Institutions. This situation indicates that the root causes of such problems may lie in specific ways of thinking within these schools, including the mindsets of teachers who teach in them and which are likely to impede the creation of constructive relationships with students and a respected identity for this type of education.

A review of research indicated that school-based vocational education faces similar challenges elsewhere. For example, large-scale (cross-sectional/longitudinal) studies in countries as varied as England, Denmark, Holland, USA, Australia, and Belgium show that upper-secondary vocational schools/tracks have low social standing, mainly attracting students from low socioeconomic backgrounds who are overrepresented even after controlling for prior attainment (Boone and Van Houtte 2013; Jackson et al. 2007; Jaeger 2009; Kloosterman et al. 2009; Lotto 1988; Polesel 2010). Explanations include middle-class parents’ disapproval of vocational education and the artisan occupations for which it prepares students (Boone and Van Houtte 
2013), the low returns on academic studies for low-income individuals when time to complete these studies is accounted for (Hillmert and Jacob 2003), and the value working-class youth (especially men) attach to manual labour and its associated early employment opportunities (Morris 2008). Even controlling for these selection effects, vocational students have lower self-esteem, perform worse, and are more likely to drop out than academic route peers indicating low effectiveness of the sector in value-added terms (Polesel 2010; Van Houtte 2004; Van Houtte, Demanet, and Stevens 2012). Some studies suggest vocational education may have positive effects on low-income students' employability and wages (see Eichhorst et al. 2015 for a review) yet sceptics note that these are limited to low-status jobs not allowing for status change (Lotto 1988; Polesel 2010). Similarly, vocational teachers enjoy lower social recognition, sense of selfefficacy, and job satisfaction than their academic route counterparts (Grollmann 2008; Polesel 2010; Skills Commission 2010).

The above review indicates that vocational schools face the same problems in countries which differ in educational structures and philosophies. For example, in liberal market economies (e.g. Australia, England) school-based vocational education is differentiated from academic routes mainly by its (lower) curriculum status offering narrower, skills-based programmes of study. In coordinated market economies (e.g. Holland, Denmark) vocational schools/tracks are mainly differentiated by curriculum specialism; their curricula are generally of equal status to academic ones combining practical skills training with systemic theoretical knowledge. Vocational school leavers in these countries are licensed professionals with recognised expertise in niche areas, who enjoy certain employment rights (Murray and Polesel 2013). Even in these contexts, however, vocational schools have relatively poor outcomes and low social 
standing (as the earlier review shows) indicating the persistence of these problems across systems and structures.

\section{The Greek context}

School-based vocational education is provided in Vocational Lyceums which, together with General (academic-oriented) Lyceums, constitute the upper (post-compulsory) cycle of secondary education (3-year full-time study). No formal streaming operates in the system and students can easily move between school types. Upon completion of studies, vocational students can sit the higher education entrance examinations alongside their academic track peers. Alternatively, they can continue studying in postsecondary training institutions or seek employment.

Vocational Lyceums offer a broad curriculum combining substantial amounts of general studies, systemic theoretical knowledge in specific occupational fields, and practical experiences. They aim to develop specialists with holistic understandings of their occupation, able to undertake complex open-ended tasks in their workplace, as well as being active citizens (CEDEFOP 2014). Hence, vocational students are not deprived access to the systemic disciplinary knowledge needed to exercise agency in occupational fields, identified as reason why social hierarchies are perpetuated in Anglophone countries with a liberal market economy (Wheelahan 2016). In fact, Greek upper-secondary education is close in structure and philosophy to that of the coordinated market economies described earlier.

Empirical data, however, reveal societal disregard of Vocational Lyceums. Only 25\% of Greek families opt for this education type most of whom have low socioeconomic status ${ }^{3}$. Dropout rates are more than six times those of General Lyceums. Among those sitting higher education entrance examinations, one third achieves a pass mark compared with two thirds of students from General Lyceums. Six 
years after completing school, vocational students are in jobs much lower in prestige than those of students who have completed General Lyceums (Paidousi 2016; Pedagogical Institute 2006, 2008).

The relevance of culture

As mentioned earlier, vocational schools’ poor outcomes are associated with troubling feelings of futility among staff and students. In a national (mixed-methods) study of Vocational Lyceums in Greece, most teachers described their students as less able and less motivated than those of General Lyceums (Ministry of Education 2011) and similar findings were reported earlier by Sotiropoulou (1998). Such teacher disregard is readily perceived by students. In the first study, students bluntly stated that teachers thought of them as being troublemakers, having low IQ, and no interest in knowledge. They also noted that teachers were narrow-minded and outdated in approaches despite their pedagogical training (Ministry of Education 2011). Such low levels of respect between teachers and students may, in fact, cause the high rate of juvenile delinquency in these schools (Georgiou 2007; Kourakis, Zagoura, and Galanou 2004). Widespread feelings of futility have also been reported in international research of vocational schools showing that teachers believe students are 'unteachable', reducing students' motivation and study involvement (Kelly and Prince 2009; McCulloch 2005; Van Houtte 2004; Van Houtte and Stevens 2010). Overall, both in Greece and elsewhere vocational schools tend to be viewed as a pathway for channelling 'weaker' students.

The above research findings, however, merely describe attitudinal phenomena without identifying their root causes. They provide little insight into teachers' deeper systems of beliefs about education and society which may explain why they think vocational students are 'unteachable’ and why they cannot see a promising (alternative) future for this education type. Such belief systems may be the reason of failure to bring 
about second-order change in vocational education - or what Fullan $(2007,15)$ refers to as 'reculturing' - even by introducing favourable structures such as enriched curricula or professional licensing. This accords with organisational theory postulating that culture profoundly (and unknowingly) affects organisational life (Schein 2010) and with research indicating that structural reforms may be implemented in completely different ways (including ways not initially intended) by people with different mindsets as these are bound to generate different interpretations of the new structures (Gordon and Patterson 2008; Thornberg, 2010).

The purpose of this study

This case study was driven by a desire to enter a typical vocational school of Greece and decipher the deeper levels of teachers' culture, i.e. their tacit assumptions about what education is, its place in society, teachers' role, and students’ nature (Hoy and Miskel 2013; Van Houtte 2005). It was premised on the belief that, unless such latent understandings are revealed and articulated, no structural reform or improvement initiative may be successful.

The study complements the predominantly large-scale research reviewed above by aiming to substantively explain teachers’ reported sense of futility in vocational schools, instead of merely describing the phenomenon or attributing it to their seeming inability of producing 'valued' outcomes with current student intakes. A 'substantive explanation' is defined here as one that captures teachers' broader 'worldviews' (van der Kooij, de Ruyter, and Miedema 2013, 210) or 'frames of reference’ (Van Houtte 2005, 79) which include their fundamental understandings of human nature and societal functioning. Three research questions were developed as the study progressed:

- What are teachers' assumptions about education and society in a typical Greek Vocational Lyceum? 
- Based on these assumptions, what subcultures might be identified and how do they differ in their interactions with students and each other?

- How might teachers' dominant culture and/or subcultures explain current misinterpretations of the role of vocational education and the ensuing futility feelings in the sector?

\section{Conceptual framework}

A central concept guiding the study was Pupil Control Ideology (PCI) developed by Willower, Eidell, and Hoy (1967). This defines school culture based on the extent to which teachers exercise control over student behaviour. Such control has been found to be an integrative motif of school life in previous studies (Hoy 2001; McNeil 1988; Willower and Jones 1963). Educational researchers and trainers have aimed at enhancing student control by focusing on 'classroom' or 'behaviour management' (Greenberg, Putman, and Walsh 2014). The concept of control is consistent with functional theory postulating that education contributes to maintaining order and stability in society (Ballantine and Spade 2015).

PCI refers to two antithetical philosophies of control in educational settings, each of which produces different understandings and operationalisations of teaching and learning. Custodial ideology emphasises external hierarchical control. Students are positioned as subordinates to teachers and expected to comply with their decisions. Behaviour is regulated through externally-defined norms and rules protecting teacher status. Misbehaviour is often (though not always) understood moralistically, as student irresponsibility or insult to teachers, leading to stereotyping. Learning is thought to occur through one-way communication flowing downwards (Hoy 2001). Humanistic ideology assumes equal status of teachers and students. The latter are trusted as competent and responsible. Self-regulation is substituted for external control and socio- 
psychological explanations of 'misbehaviour' prevail. Learning is understood as knowledge creation by students through cooperative interaction and experience (Hoy 2001).

In reality, most teachers would be relatively custodial or relatively humanistic on the custodial-humanistic continuum (Hoy 2001). A teacher's orientation is not static, but may change with experience or context. Teachers may be more or less humanistic towards certain student groups depending on their trust in those students' ability or credibility (e.g. working-class versus middle-class students) and the perceived threat they pose to teacher status (e.g. secondary versus primary students) (Karakus and Savas 2012; Lunenburg and Mankowsky 2000). Teachers’ need for external control is particularly fortified in schools serving low socioeconomic status populations (Beachum et al. 2008; Gordon and Patterson, 2008) where students often express disruptive resistance not least because their needs/cultural capital are unrepresented in curricula, formal structures, or cultures, resulting in what Bourdieu termed 'symbolic violence' (Bourdieu and Passeron 1990, 4).

Even though PCI primarily refers to teacher-student relationships, it also reflects wider power asymmetries among school members. Schools with custodial orientations have been found to exhibit bureaucratic characteristics. Centralisation is high with the Principal having the largest control span, formal rules predominate, professional relations are impersonal, and opportunities for developing pedagogical competence through dialogue are limited (Lunenburg and Mankowsky 2000). In custodial environments, peer pressures can result in teachers' burnout or attrition if their espoused educational philosophy is fundamentally humanistic and they cannot deal with the encountered dissonance between the control orientation of the school they work in and their own (Dewitt 1999; Wiley 2000). 
On the other hand, a humanistic school orientation is conceptually linked to what is known as 'learning community’ (Stoll et al. 2006, 221) in which teacher interactions are lateral, personal, two-way, inclusive, and driven by a thrust for enquiry. Deliberative discussions on pedagogical matters are frequent and leadership is guided by constructivist thinking with all school members viewed as co-learners/co-leaders (Lambert 2009).

PCI, even though initially founded on organisational management theories, has close parallels with ideas developed in the fields of critical pedagogy and adult education. For example, Freire (1970) argued that schools are always political and aim either at reproducing the status quo or empowering students to transform society. The first is achieved through a 'banking' approach to learning (Freire 1970, 53) whereby 'objective' knowledge is transferred from 'expert' teachers to 'ignorant' students (custodial ideology). The second is achieved through problem-posing and transformative action based on two-way dialogue and cooperation (humanistic ideology). Similarly, Knowles $(1977,202)$ juxtaposed the concept of 'pedagogy' (children's education) with ‘andragogy' (adults' education). The first refers to teaching narrow skills to dependent personalities (custodial ideology) while the second views learning as self-directed enquiry by independent personalities who build on personal experiences (humanistic orientation). Humanistic principles are also evident in Dewey’s (2008) concept of democratic education.

\section{Methods}

The setting

The school was an evening urban Vocational Lyceum (7.00pm-10.35pm). Evening Lyceums represent 19\% of Vocational Lyceums in Greece, providing flexible 
attendance arrangements for those aged 15 years or older who work during the day. The school comprised departments representing male-dominated occupations, which, to protect anonymity, are not identified here. Together, these specialisms attract $67 \%$ of all Vocational Lyceum students in Greece (Paidousi 2016).

In the year of study (2010-2011) the school enrolled approximately 300 students (85\% men, 15\% women) aged 15-55 years. One third had reached legal adulthood $(\geq 18$ years). Another $16 \%$ came from immigrant families. Students were either employed or jobseekers, mostly representing lower-middle or working classes (60\% of parents had completed lower-secondary education or less).

The school had 40 teachers (34 men, 6 women) aged 32-59. Teaching experience ranged from two to 31 years, with an average of 16 . The school suffered from high staff turnover among general subjects teachers, who viewed the school as a transitional career stage expected to lead to a better post in a General Lyceum. At the time of fieldwork, 51\% of teachers had worked in the school for less than six years.

The above characteristics were in line with national trends in the sector as depicted by the Greek Statistical Authority (ELSTAT 2011) and hence, the school was considered a typical case. Given its accessibility, it became the study’s focus. In the years preceding the study, the school had experienced significant growth in student intake and increasingly gained reputation in its local community. The Principal had made efforts to publicly promote the extracurricular projects and academic successes of some of its students through media and events to which eminent public figures were invited. Yet, over the past years, the school had also suffered from occupation protests ${ }^{4}$ during which many students had insisted on improving their educational experience. According to a Health Education Project conducted by students in the year preceding the study, and which formed part of the documentation researchers had access to (see 
‘data generation’ section below), 50\% of students had reported negative feelings during time spent in school, including boredom, apathy, tiredness, or feelings of 'imprisonment'. Therefore, the school constituted an interesting case for examining invisible aspects of teachers' culture that could help explain broader problems of disengagement and low morale in the sector as viewed through this one particular context.

\section{Data generation}

The case study methodology was deemed appropriate for the in-depth examination of teachers' culture. A core feature of case study research is the use of multiple methods to generate rich data, enhancing data credibility when exploring complex phenomena (Yin 2009). Fieldwork was conducted between September 2010 and June 2011 and included: a teachers' survey; interviews with teachers; teachers' written narratives; observations of interactions during arrival at school, break time, departure, formal meetings, assemblies, and informal discussions in staff rooms (all recorded by field notes spanning the entire school year); document analysis (minutes of meetings, school articles in local newspapers, etc.); and photographs of school artefacts.

Informed consent for the study was initially given by the Principal. Consent for observations, document analysis, and photo-taking was provided by all teachers and elected student representatives during a meeting. Separate consent was also sought from each survey and interview participant, and those providing written narratives. All observations of teacher-student interactions took place outside the classroom. Participants were always informed of their occurrence and invited to opt out if they wished. Fieldwork was conducted by the second author.

In this paper, the researchers focus on reporting data from the teachers' survey, interviews, and written narratives. Data from field notes and school documents are also 
used sporadically (i.e. three times in this paper) when data from the other sources do not allow for an adequate illustration of emerging themes. The three main types of data reported in this paper are detailed below.

Firstly, the teachers' survey aimed to give an overview of the school’s PCI before exploring teachers' underlying belief systems. It also guided the selection of interview participants. Teachers’ PCI was measured using a 20-item Likert-type scale developed by Willower, Eidell, and Hoy (1967) known as 'PCI Form'. This has been widely used in previous studies generating high reliability/validity indicators in countries such as USA, Turkey, South Africa, Canada, Israel, and Australia (Abu Saad and Hendrix 1993; Bas 2011; Gilbert 2012; Hoy 2001; Karakus and Savas 2012; Ngidi 2012; Packard 1988; Rideout and Windle 2013). Unlike other scales measuring teachers' educational philosophies at a rather theoretical level (e.g. constructivism versus traditionalism) and which do not always match actual pedagogic behaviour (Bolhius et al. 2004; Hermans, Braak, and Van Keer 2008; Silvernail 1992; Rideout and Windle 2013; Woolley, Benjamin, and Woolley 2004) the PCI Form has been found to be closely associated with teachers’ actual practice as assessed by students (Blust and Willower 1979).

Example items on the PCI Form include: 'pupils can be trusted to work together without supervision' (reverse coded); 'it is justifiable to have pupils learn many facts about a subject even if they have no immediate application'. Teachers are asked to indicate whether they agree or disagree with each item using a five-point scale on which each point is labelled. Scores may range from 20 to 100 with a midpoint of 60: the higher the score the more custodial the ideology. Thirty-five out of 40 teachers in the school completed the PCI Form in October 2010 which was translated in Greek. In this small sample, the scale’s Cronbach’s Alpha was 0.75 . 
Secondly, after analysis of PCI data (December 2010), teacher interviews were conducted (March - May 2011). Care was taken to represent teachers with different PCI scores, genders, specialisms, teaching experience, and years in school. Twelve teachers were interviewed including the Principal and two Vice Principals. Interviews occurred in a quiet school room, and were audio-recorded and transcribed. Teachers were probed to talk about relationships with students and colleagues, teaching and learning, the purpose of schooling (especially vocational schooling), student achievement and behaviour, formal structures, decision-making, leadership, and critical events such as the students' occupation protest.

Thirdly, three teachers wrote reflective narratives of a typical school day (February 2011) encapsulating feelings and thoughts about daily school experiences (condensed meaning of their work). Table 1 presents the characteristics of teachers participating in interviews and of those providing written narratives. Pseudonyms have been used.

\section{[Table 1]}

\section{Data analysis}

Data generated through the PCI Form were analysed descriptively to provide a summary of the school's pupil control orientation. Data generated through interviews and narratives shed light on aspects of teachers' culture not captured by the survey. Hence, quantitative and qualitative data analysis was guided by a motivation of complementarity (Small 2011).

Qualitative data analysis was informed by a social constructionist epistemology according to which the ways people understand the world represent constructed (rather than objective) realities in specific socio-historical contexts of which different versions 
may simultaneously exist (Lyons and Coyle 2016). To uncover such versions of teachers' constructed realities (subcultures) in this Vocational Lyceum, the researchers drew insights from discourse analysis and focused on differences in language use (Johnstone 2008).

Patterns of meaning in the qualitative data were identified through inductive thematic analysis (Lyons and Coyle 2016). Codes were developed by naming text segments deemed important and grouping these to form themes. Themes were gradually refined through an iterative analysis process including an ongoing literature review. Six interviews and one narrative were initially analysed to build a model which was then tested against other interviews and narratives and gradually refined. Data were initially coded by each researcher independently and then compared and discussed until agreement occurred. As the researchers already had a grasp of relevant literature, theoretical concepts unavoidably guided data interpretation. Pure induction cannot, therefore, be claimed. Yet, at the beginning, the analysis was mainly informed by the PCI concept as developed by Willower, Eidell, and Hoy (1967). Insights from critical pedagogy and critical social theory were brought into the analysis later on as a result of themes emerging inductively.

\section{The school’s Pupil Control Ideology}

Most teachers (62.8\%) scored above 60 on the PCI Form, while a significant minority (28.6\%) scored below 60 . Three (8.6\%) scored precisely 60 which is the scale's midpoint. The mean and median values in the school were $63.3(\mathrm{SD}=8.9)$ and 64 , respectively (Table 2).

[Table 2]

Periklis (the Principal) scored 69 on the PCI Form which denotes a relatively custodial 
ideology. In his interview, he described his leadership as 'an oligarchy...using an elite of teachers with the qualifications and abilities to make good decisions'. His approach was, therefore, centralised, distributing responsibilities to a select few. Other teachers with a relatively custodial PCI ( $>60)$ formed informal groups which seemed to be rather insular and with an established outlook on school matters.

What brings us together is the sharing of common thinking. (Lefteris)

In my circle of colleagues, we discuss school problems...I only mix with people interested in school matters...most times we agree on what needs to be done.

(Antreas)

Teachers with relatively humanistic PCI $(<60)$ did not appear to belong to such groups as Evi noted: 'I am not that close to colleagues but not too distant either'.

The above data indicates that teachers with a relatively custodial orientation were more bonded and vocal in the school. Below, the interviews and narratives of teachers scoring above 60 on the PCI Form are analysed and compared with those of teachers scoring below 60 to depict and discuss contrasting elements of these two subcultures.

\section{Dominant custodial subculture: hierarchical order/control}

A core theme in the talk of all teachers with a relatively custodial PCI was preoccupation with order, stability, and control in life. Such order was regarded as prerequisite for peaceful coexistence and even learning.

I, both in my life and in school, I like order. I don't like going beyond limits...I want respect to exist, mutual understanding, being able to communicate, to cooperate...to be able to conduct the lesson. (Alexis)

Teachers suggested that such order would be ensured if some individuals had more 
authority and responsibility than others, implying that power asymmetries between people (i.e. hierarchy) were legitimate: ‘Teachers have full responsibility for students’ health and safety. Therefore their role must be a little bit higher' (Orpheas). People were ranked on this hierarchy according to some valued dimension, including socioeconomic background, formal credentials, or age. Occupying a higher rank was often equated with being intrinsically better, or in other words, occupying the place to which one naturally belonged.

I don't believe colleagues are malevolent. This wouldn’t be in line with the high standard of education they've received. (Orpheas)

It is not easy for a 50-year-old student to get down to the level of an 18-year-old. (Alexis)

The constructed/arbitrary character of social hierarchies (Bourdieu and Passeron 1990; Giroux 1997) remained largely invisible to all custodial teachers. Their ideology was subtly articulated in their interviews/narratives generating certain views about the purpose of schooling, students' nature, and the meaning of teaching/learning, as portrayed below.

The apolitical (functional) school within the natural social order

All custodial teachers described the purpose of schooling as preparing students to 'enter', 'effectively function', and 'have respect' in society as it is currently known. Such preparation was considered unproblematic, while the world it was aimed for was seen as normal or unchangeable. The unproblematic nature of school preparation was evident when teachers used cliché words to describe educational outcomes considered important - being 'correct', 'good professional', or 'knowledgeable' - without reflecting on deeper meanings. These qualities implied that students conformed to taken-forgranted social mores. 
Interviewer: When you say 'correct', it’s a bit abstract...

Alexis: I'm getting a bit tired. Just a minute... We could say a 'correct' person is morally upright. You'll tell me that this is also abstract. Eh...to be cooperative... what else?

Most teachers referred to the importance of students being 'cooperative' with which they meant being non-disruptive and docile. Other valued qualities included 'responsibility’, 'logic', 'hard work', and 'reliability’, all reflecting conformism. Disruptive disagreement or conflict were undesirable. The alienated, yet quiet, student was not considered as much of a problem as students who openly challenged lessons, as Andreas described: 'Indifference on its own doesn’t create problems...Problems are created when a student wants to disturb...to show his individuality’.

The school was depicted by custodial teachers as a space separate from society where (undistracted) students could develop qualities necessary to adjust; a social ‘oasis’ often contrasted with injustices encountered ‘outside’ in real life. Teachers viewed themselves as selfless individuals serving students with the best intentions in an almost evangelical way. Thus, the school was believed to be apolitical and a priori good: 'The school is a space that protects the child. Upon leaving school, the child, outside, will have to fight with other factors' (Orpheas).

\section{Sympathetic (deficit) view of students}

Students brought with them working-class cultural elements, namely 'lived knowledge', ‘informality’, and 'labour power’ (valuing work more than school) (Lawrence 1986, 16) as illustrated below. 
Students aren’t interested in solving exercises...But if you ask them to design a tool recording how much petrol motorbikes consume relative to acceleration they can do it [puzzled]. (Melpo)

I could never imagine there're students with no manners...he opened the door without knocking! (Melpo)

Students are indifferent to knowledge...that's the problem. (Thomae)

Such cultural attributes were little esteemed by teachers with a custodial PCI, generating a deficit view of students positioned in the lowest ranks of social hierarchy. Most teachers considered students unable to master legitimate (school-type) knowledge or follow school norms (understood as 'misbehaviour'). Such inability was often essentialised and explained as intellectual, moral, emotional, or even genetic, weakness. Antreas, Melpo, Lefteris, Stavros, and Periklis (the Principal), characterised the school as ‘special school' or ‘child minding institution' and students as ‘requiring a specialist'. As McGarr and McCormack (2014) argued, such essentialist view freed teachers from responsibility for student failings, which were, instead, attributed to students’ low ‘teachability’.

This deficit view of students was compounded by their unfavourable life circumstances (such as poverty or dysfunctional families) creating feelings of sympathy among custodial teachers.

I feel sorry for these guys...A student has experienced his mother's attempt to commit suicide, another one lost his mother during labour and grew up with his grandfather, a third one doesn't know where his mother is years now, and a fourth is a gigolo to maintain his family. (Andreas)

He’s 30 years old and doesn't have $€ 1$ to eat. (Lefteris)

In all custodial teachers' views, students not only lacked the ability, but also the welfare conditions necessary for accessing the (supposedly) higher cultural capital ${ }^{5}$ the school represented. As a result, teachers found meaning in showing compassion to these 
vulnerable individuals: 'We become comforters' (Antreas). Paradoxically, this sympathetic attitude was likely to further disempower students, holding them more firmly in their subordinate position of dependence for which they were being sympathised. As Herr and Anderson (2003) argued, teachers' sympathy became itself a tool of student control.

Heroic exceptions and social mobility: the justice of merit

There were students who, in some teachers' views, were resilient enough to achieve against odds, succeeding academically and/or professionally.

Some school leavers took up good posts in big telecommunication companies...Their abilities and natural desire for learning allowed the school to help them learn. (Andreas)

Teachers often described these students as ‘heroes’ who, despite initial disadvantage, managed to move up the social ladder based on merit. Such exceptions gave teachers a sense of purpose, 'an expectation that good and clever students won't be wasted' (Stavros). This minority who 'turned around' further legitimised traditional school practices and reinforced teachers' assumption that the causes of poor/good performance lay within the individual. This was evident in most custodial teachers' labelling of students as 'good/bad', 'bright/slow', or 'adaptive/maladaptive'.

The above reflected a meritocratic assumption that the most talented and/or industrious individuals would achieve more in life. The school, as a benevolent and just institution, should offer the same opportunities to all, so that each student could succeed according to 'merit'. As argued by McGarr and McCormack (2014), this apolitical way of thinking comes as no surprise given that many custodial teachers (5 out of 8 in our study) were once low-income students who, having succeeded in school, were now 
enjoying advanced socioeconomic status: 'We studied hard when we were young....Nothing was given away to us’ (Alexis).

Custodial teachers' belief in merit and the inevitable inequality this produced also applied to colleagues, who were depicted as having different degrees of ability: 'Some teachers just can’t...They lie off Gauss’ distribution' (Periklis). Apart from the Principal, Stavros, Lefteris, Antreas, and Melpo also expressed such views.

\section{Positivist-behaviourist pedagogy}

Custodial teachers’ espoused pedagogy echoed positivist and behaviourist learning theories based on: teacher authority; transmission of prescribed knowledge; student objectification; and preoccupation with managing behaviour (Giroux 1997; Rogers and Horrocks, 2010). This pedagogy constituted the core school technology for preparing functional citizens reflecting an ‘instrumental ideology’ (Littledyke and Manolas 2010, 291) or a 'banking' approach to education (Freire 1970, 53).

Teacher authority

Teachers had central control in school. They occupied a fixed position ranked higher than students. Descriptions of themselves as 'master', 'big uncle', or 'father' symbolised status. Protecting this status was a main concern, often resulting in inauthentic behaviour and manipulative tactics, causing student anger.

I always support the teacher. Even if s/he is at fault. Otherwise s/he will lose face. The student is later compensated with a kind word or the deletion of absence points. One time, however, I had to call the school councillor because students were enraged. (Periklis, Principal)

School knowledge: theoretical, objective, fragmented Although some custodial teachers recognised the importance of students' lived 
knowledge, most believed schools were mainly responsible for developing theoretical knowledge. The latter was portrayed as independent of student experience, objective, and controlled by experts: 'The curriculum has been developed by...technical education experts. And we should follow it' (Alexis). This knowledge was separated into wellbounded disciplines with pyramidal structures:

Each teacher is expert in their own field. (Orpheas)

When students cannot learn new topics, I insist in teaching them previous ones so that they can reach the level necessary to progress to the next. (Antreas)

Teaching as rational process

The above view of knowledge generated an understanding of teaching as rational process. All custodial teachers conceptualised teaching as described by Lawrence (1986, 19) namely as 'passing on to students agreed truths and bodies of knowledge which... experts over the years have deemed to be that which students should know'. One-way monologues were commonly used by teachers who 'transmitted', 'presented', or 'explained' disciplinary content and objectified social mores to students. Lefteris argued: 'I can teach any topic in any class as long as I understand the content'. When asked what makes for effective teaching, Thomae referred to 'time', 'audio-visuals', and 'technically-oriented content'. Content and resources were, therefore, considered key elements of quality teaching, indicating the largely unproblematic character of pedagogical practice.

Learning was considered separate from teaching, taking place after transmission of knowledge and understood as assimilation of this knowledge by students who passively 'listened to the teacher'. Learning was disconnected from authentic life experiences, occurring in dedicated spaces (classrooms, free time slots) as Alexis implied: 'Students don’t have free time to study... when they need to make a 
living, they inevitably put work first and knowledge second’. Such separation necessitated the use of external incentives to motivate students to study as Periklis (the Principal) highlighted: ‘Teachers satisfy a students’ want, they may talk about football and morally oblige them to attend the class'.

Measurement and monitoring

In line with their rationalistic view of pedagogy, all custodial teachers emphasised quantity in teaching and learning, the effectiveness of which was believed to depend on the volume of teachers' disciplinary knowledge and students' ability to absorb this: 'You tell them 10 things to retain 4, 5, 6...as much as each student can' (Orpheas). Measuring the volume of student learning was a primary concern. Results of such measurement (referred to as 'student performance') helped teachers control student activity and produce certain desired outcomes by informally 'sorting students' into ability groups and 'pressurising them to study the given curriculum' (Thomae).

Some custodial teachers also emphasised teacher monitoring to enhancing educational outcomes, mainly because they were disappointed with corruption and micro-politics in public education, a chaotic organisational situation believed to be rectifiable only through heightened external control ${ }^{6}$.

Since there's no external, objective evaluation, teachers aren't interested in doing a better job... and I don't believe we can change the jungle we live in. (Lefteris)

\section{Behaviour management}

Student behaviour was a dominant concern of all custodial teachers who believed their school faced serious problems.

It's a matter of time for us to become a headline. (Andreas)

If you don’t pay attention to behaviour, what else will you attend to? (Orpheas) 
Misbehaviour was understood as anything challenging teacher authority, such as ignoring teacher-defined rules (delinquency) or not valuing teachers' expert knowledge (indifference) as Melpo commented: 'Disregard for the teacher...sleeping during class...anything creating disruption...pointless interruptions of a lecture...discussing with classmates’.

Behaviour management was considered an important ability, which, together with subject knowledge, determined teachers’ competence. Most custodial teachers viewed student misbehaviour as reflecting teacher weaknesses, such as 'poor subject knowledge', 'limited skill', or 'personality issues'. They described softer and stricter approaches to dealing with misbehaviour all geared towards convincing the student of wrongdoing (often under the guise of care) and regaining teacher control.

I talk to them a lot...highlighting the dangers of non-attendance...for their own benefit. (Thomae)

He answered his mobile phone in classroom... He insisted it was a call from work. At break time...I said: 'What sort of behaviour is this in classroom?’ He said:

'Other teachers let us talk'. I said: 'Look, I’ve heard this excuse many times. It's become a fashion... Better tell me something else. You know the classroom rules...You showed complete disregard for me. You don't have the right to ignore a working professional... Do you like being ignored at work?' He finally apologised. (Melpo)

In fact, student apology indicated submittal to teacher authority and was often enough to avoid penalties.

Custodial teachers also attributed student misbehaviour to the softer, and supposedly transactional, approaches of colleagues with a more humanistic orientation: ‘They give students good marks, make good deals, and are trouble free' (Stavros). Such approaches were viewed as negatively reflecting on custodial teachers reducing their 
ability to manage students: 'Some teachers have lowered their standards and this is affecting all of us...because I come across as the bad guy’ (Antreas).

\section{Deceptive student voice}

Custodial teachers' espoused pedagogy resulted in students having little say in what, when, and how they learned. Their classroom behaviour was strictly controlled, 'knowing well that when it's time to give a class, I'll give the class....while cheerfulness requires cheerfulness' (Andreas). Student critique of classroom practice was generally unwelcome: 'It hasn`t happened to me yet. I hope it doesn't' (Lefteris).

Most teachers, nevertheless, believed school was democratic, reducing the notion of democracy to sporadic expression of opinions as Thomae's words indicate: ‘Students can make suggestions, they’re allowed to exercise their democratic rights...but this doesn't mean their opinion will be respected if it conflicts with school rules’. The narrowness of this democratic space was justified based on student irresponsibility and/or indifference: ‘Students don’t want, they’re tired...they don’t have interests...to make a decision about what?' (Lefteris).

Student voice was often used tokenistically to manipulate students in an essentially undemocratic environment. Occupation protests (key symbol of student voice) are an example of this tactic. According to fieldwork notes, students occupied the school for a month in the year of the study. Demands included 'upgrading infrastructure', 'disinfecting the building', and 'repairs of nearby roads' (school council letter to the Principal). The Principal allowed the protest to proceed, despite it being illegal. He forwarded student demands to the Local Education Office but took little action explaining, in his interview, that 'students occupy the school to socialise, to feel 
strong'. Later, when he sensed the occupation could damage the school's reputation, he abruptly terminated the protest and student demands were soon forgotten.

\section{Futility culture and nostalgia of the past}

A sense of futility permeated most custodial teachers' talk. They were dismayed by their inability to achieve valued outcomes (knowledge- and behaviour-wise) locating the causes of such failure in the student intake over which they had no control: 'I feel sad thinking of students' background... I can't work with them the way I had dreamed' (Stavros). Lefteris attributed school dysfunctions to the partiality of those in power and their corrupt governance: 'Superintendents are selected on a partisan basis, they're of questionable ability and intent'. Such critique focused on individuals, leaving deep ideological assumptions and structures unquestioned. This apolitical, and partly micropolitical, thinking blinded teachers to any meaningful transformation as apparent in Andreas’ talk: ‘I don’t have any hope about technical education’.

Overall, custodial teachers expressed a pessimistic outlook on the future, looking back nostalgically to the past; the 'good old days' of higher standards and control: 'Our society is losing its values...Compared with my days, when I was a student, standards have been severely downgraded' (Stavros). Consequently, they experienced a low sense of meaning in their work and talked contemptuously about their school as Melpo’s exclamation shows: 'This school is useless!'

\section{Humanistic subculture: empowering students for change}

Ten teachers (Table 1), including two elected Vice Principals (VPs), had a relatively humanistic PCI. They had little organisational influence, being a minority in a school with custodial leadership and strong custodial groups (VPs had only a substitute role in the management of the school). Their fundamental assumptions about education and 
society are described below.

Looking towards the future: transformative education

Most teachers with humanistic orientation envisaged a transformative school. Change was seen as natural in life; a prerequisite for progress. One needed to look into the future to seek new solutions to problems rooted in the past. This felt a difficult learning process:

If we don't put the word 'future' in our minds, as teachers, we can’t operate... But the future frightens us. It requires pain. Some teachers can’t see the new. (Yiannis, VP2)

The change these teachers desired would involve new ways of thinking and living, leading to broader socio-economic restructuring by (possibly) eliminating hierarchies.

The dirty man who used to be the auto mechanic...he should now be the doctor who's dealing with your vehicle that transports you every day and on which your life depends...that's the status he should enjoy. (Christos, VP1)

\section{Valuing and empowering students}

Most teachers with a humanistic PCI believed change would occur through student empowerment as Yiannis (VP2) suggested: 'These young people are the future of our country. We're the past...We must let them blossom'. Empowerment meant promoting students’ agency in society; helping them become creative and critically-thinking professionals: 'We want students to be productive, able to construct rather than simply repair... and able to exercise judgement' (Christos, VP1).

This vision was based on teachers' trust in all students. Positive comments about students were abundant in their talk. They communicated high expectations for all, carefully using language to avoid labelling: 'I believe all students are very 
good...they've many things to tell you. They're keen to discuss and explain events from work, school, or life' (Lili).

All humanist teachers described students as 'professionals', 'partners', or ‘friends' implying equality of status and drawing attention to the reciprocity of relationship: 'You learn from students' (Filippos). They talked about mixing with students in friendly ways, 'saying 'hello’ and teasing each other' (Simos). Field notes indicated they also socialised with students outside school.

Finally, all humanist teachers acknowledged their accountability to students, seriously taking their critique into account and recognising students’ power of choice as adult learners.

\footnotetext{
Students are strict and just judges. Their critique is well-intentioned...they want to help, and to help primarily themselves...I wouldn't want my subject become an obstacle to other commitments students have and which are much more important to them. (Filippos)
}

\section{Humanist pedagogy}

In talking about classroom practice, teachers (unknowingly) articulated key principles of what Rogers and Horrocks $(2010,103)$ described as 'humanist theories of learning' and which compare with paradigms such as andragogy (Knowles 1977) and constructivism (Fosnot 2005). Students were described as actively 'producing knowledge' (Christos, VP1) by pursuing self-determined goals. This involved meaningmaking through reflection on one’s own experience as Filippos argued: 'Through the lens of their own experience, students can more easily participate in classes'. Some teachers emphasised students' ownership of learning by questioning the school's indispensability: 'Whatever they want to learn, they'll learn it whether they come to school or not' (Lili). 
The frequent use of verbs such as 'linking', 'bridging', 'marrying', or 'combining' indicated these teachers' interdisciplinary practice. Such connectionmaking generated holistic (critical) understandings of the world. Students were depicted as 'discussing', 'talking', 'working in groups', or 'making unique contributions’ indicating the centrality of collaboration based on the principles of complementarity and inclusivity. Disagreements were regarded as opportunities for mutual understanding as highlighted by Filippos: 'Different views are respected...I believe we can find common points of contact through critical discussion'.

Most humanist teachers believed valued educational outcomes could not be easily defined or measured: 'We can’t say that my knowledge costs 50,000€’ (Yiannis, VP2). Valued outcomes included self-knowledge, joy, happiness, self-fulfilment, ability to communicate, and the long-term progress of society.

I want to see students coming with a smile and leaving with a smile... when I'm properly educated I know what I want...good education brings happiness...we'll see the result in the progress of society. (Christos, VP1)

Concern for student behaviour was low among humanist teachers. They often attributed misbehaviour to the faculty's custodial orientation, suggesting problems could be overcome by empowering, rather than controlling, students as Christos (VP1) stressed: ‘We’ve some problems, not many...mainly because teachers could have a different approach vis-à-vis students...Behaviour can be improved when students feel useful' .

\section{The reflective professional}

All teachers with humanistic orientation described a good teacher as a 'self-reflecting', 'learning professional' instead of a master/expert. For them, a good teacher was ultimately authentic, as Lili put it: 'I conduct my self-criticism everyday...Because what 
you think you do may differ from what you actually do’.

Teachers pointed to the complexity of teaching, suggesting that pedagogic knowledge was as important as content knowledge. They highlighted the seriousness of their profession, recognising the lasting impact of their actions on students: 'Our profession is dangerous. Students can pay an entire life for teachers' mistakes' (Yiannis, VP2). Such self-reflective attitude often generated sharp criticism of the purposes and outcomes of schooling: 'Students view the school as something torturous...offering sterile knowledge. Why should anyone come to school after all?' (Yiannis, VP2).

Finally, all humanist teachers valued colleagues in the same way as students, advocating collaboration in a climate of equality and trust: 'There're valuable human resources in our school; all colleagues want to offer...everyone is part of a whole' (Christos, VP1).

\section{Positive meaning at work}

All those with a humanistic orientation talked about their job with emotion and passion. They apparently enjoyed greater job satisfaction than custodial teachers and found positive meaning in their work.

I'd like to use Wilhelm Reich's words... that work should be like hobby... all these years I tried to make time in school more pleasurable for students and colleagues...creating a playful, relaxing atmosphere so that we could do our best in classroom. (Simos)

This is a beautiful school. It grants justice. (Christos, comparing his school with General Lyceums)

\section{Teachers with inconsistent approach}

Two teachers with a humanistic PCI (Lili and Yiannis) exhibited some ambivalence in ideology and approach. Lili lacked both ideological clarity and consistency of behaviour 
vis-à-vis students, as indicated in the following words: 'When students are conscientious, I talk to them with kindness. When they don't understand, I use threats...perhaps I should be stricter right from the start? I don’t know...' Given her natural trust in students, she found it difficult to explain misbehaviour: 'I believe most students are good...I don't know...many times I've asked them what they'd be interested in doing, but they're negative to everything'. During an educational visit abroad, she noticed the trusting, equal relations between teachers and students and wondered why this was not the case in her school: 'Finnish students had a very liberal spirit...they talked to teachers informally using first names...yet they didn’t cause problems...I think we, Greeks, have misunderstood some things...I don’t know’. Yiannis (VP2) often adopted custodial behaviours despite the fundamentally humanistic beliefs he articulated. Field notes indicated he often suggested that students be assigned disciplinary sanctions. Such inconsistency was also noted in his interview: 'Many times I want to do one thing but I do another'.

It was, therefore, concluded that these teachers represented a subcategory of 'inconsistents'. Both experienced insecurity and fear of not being accepted by custodial peers, adhering to custodial norms to avoid criticism and being wary of genuinely expressing humanistic beliefs as Yiannis (VP2) admitted: 'I express my views tentatively...I've been blamed for being too soft with students'. The dissonance these teachers experienced tired them: ‘Many times, when we finish school, I don’t have any energy. I go home and don’t want to speak...I feel like a flat battery’ (Lili).

\section{Congeniality and absence of dialogue}

All interview participants positively commented on relationships with colleagues, describing these as 'very good', 'excellent', or 'best ever'. A closer look at the data, however, revealed that good relationships meant ‘colleagues don’t argue, conflicts 
quickly dissolve’ (Antreas). Further probing uncovered that the seemingly positive climate masked underlying tensions as Melpo commented: 'It’s not very apparent whether they exist [hostilities], but it seems that they somehow exist'. Sometimes, such tensions were handled micro-politically.

Some go to the Principal and suggest, for example, organising an event about AIDS... and there's the opposite group wanting to sabotage this... who go to the Principal and tell him ‘this isn’t right...we'll be blamed for missing valuable teaching time, pushing children to sex...the papers will write about us', so the Principal says ‘better not do it'. (Lefteris)

Tensions were also due to the ideological clash between the custodial and humanistic subcultures. As depicted earlier, each subculture often located the causes of school problems (e.g. student misbehaviour) to the stance of the other. As Yiannis (VP2) noted, such ideological differences often led to conflict: 'If we see something differently, we don't have the experience or knowledge to reach a high level of dialogue. We may even fight'.

Overall, pedagogical dialogue was limited. Custodial teachers’ rationalistic view of pedagogy did not allow for deliberative discussions. Teachers merely exchanged practical advice on quick-fix solutions to occasional classroom problems. Collaboration was mostly contrived, taking routine forms imposed by formal structures: 'We team teach in labs, we share administration duties...I can’t think of any other forms of collaboration' (Lili). Therefore, teacher relationships in this school were rather congenial instead of truly collegial.

\section{Discussion}

In this Vocational Lyceum, two teacher subcultures with antithetical representations of education and society (i.e. custodial and humanistic) coexisted. The former was more 
established in the school, consisting of the majority of teachers and epitomised by the Principal's centralised leadership.

In line with what Giroux $(1997,10)$ describes as 'culture of positivism', custodial teachers viewed society as an objective entity whose features were attributed to some external cause beyond people’s will. Social arrangements were amenable only to modest changes aimed at optimising the status quo. The latter had an essentially hierarchical structure attributed to natural inequities in human worth; it constituted the structural surface of an inherently unequal humanity. This worldview entailed elements of an individualistic ideology attributing success or failure to individuals, leaving unchallenged societal structures (Grimaldi 2012; Rassool and Morley 2000). This was evident in teachers’ essentialist explanations of student failings in this Vocational Lyceum and their deficit views of them as depicted in the findings.

Custodial pedagogy drew on the above frame of reference. Teachers aimed to optimally develop existing human resources (students) through a rational pedagogical technology - what Giroux $(1997,8)$ refers to as ‘technical mastery of human beings’. They aimed to maximise learning (acquisition of 'objective' knowledge/mores) within the limits of students' inherited capabilities, so that they could be granted a position in the social hierarchy based on merit. This functional (Ballantine and Spade 2015) and instrumental (Littledyke and Manolas 2010) ideology urged teachers to identify the most promising individuals - a sort of talent-hunting - so as to invest in them their best efforts and achieve maximum gains (efficiency). This was evident in the emphasis teachers placed on a small number of 'heroic exceptions' who managed to do well in school despite initial disadvantage. As discussed in the findings, it was these exceptions that gave custodial teachers some sense of purpose in their work. 
Our data indicate, however, that custodial teachers did not only ascribe instrumental dimensions to their practice, but also deeply moral ones. From a moral perspective, it would only do justice to those deserving, if teachers helped them progress, including students in difficult life circumstances who managed to change their position from being 'vulnerable' to being 'exceptional'. Similarly, it would only serve the collective good if teachers contributed to the growth of human capital by ensuring that important social and professional positions were filled by the most able who could better serve societal progress. To use Bourdieu’s term (Bourdieu and Passeron 1990, 31), teachers 'misrecognised' merit-based social mobility as justice. In reality, they helped perpetuate socially constructed inequities, heighten control, and restrict democracy through their benevolent custodialism.

Students’ working-class background restricted teachers’ access to presumably 'good' and 'clever' individuals, which, as reported in the findings, did not allow them to produce desired (legitimate) outcomes. Vocational students' community- and workbased culture/knowledge were misrecognised, generating a deficit view of them as lacking essential qualities for success. Student failure was seen as an unsolved problem in this school and teachers communicated a strong sense of futility in line with research reported in the Introduction. Teachers were further disillusioned by students' adult profiles which often denied teacher authority, such as the student who answered a workrelated phone call during class.

Some teachers found meaning in their 'sympathetic care' for vulnerable students, taking the role of a 'father' or 'big uncle', which - in line with previous research (Herr and Anderson 2003) - served to make a critical mass of students buy in the school by creating an impression of it being inclusive and benign. This 'solution' to the problem of meaning was inadequate, failing to create future vision. As Carrington 
and Elkins (2002) and Van Houtte (2005) observed, an adequate solution seemed impossible unless teachers' frames of reference changed. The need for such change was also indicated by the inherent inconsistencies of the custodial worldview - also evidenced in previous studies (Beachum et al. 2008) - which went largely unnoticed by teachers: care coupled with disregard for students; a will for progress coupled with attachment to the past; congeniality coupled with unsolved tensions and lack of dialogue. The deceptive nature of custodialism which does not value humans equally and limits agency and democracy was epitomised by the Principal's leadership style described by him as ‘an oligarchy’.

It is worth noting that the custodial ideology articulated by Greek teachers was not rooted in neoliberal thinking and market approaches to education driving school effectiveness movements in other countries (Wrigley 2008). For them, human capital growth was a moral imperative rather than a market imperative. When referring to 'standards', they did not imply formal benchmarking or standardised testing, while their pedagogical rationalism was not the sort of evidence-based practice described by Biesta (2007). Their practice was based on what Giddens (1985) referred to as 'practical consciousness' accessible only in action and lacking an explicit conceptual framework to support it.

Teachers with humanistic ideology expressed genuine respect for every student and colleague; a belief that all were equally worthy. They viewed diversity as source of learning and creativity rather than inequality. They understood (perhaps implicitly) that hierarchies were socially constructed. These teachers did not merely critique existing hegemonic structures, but talked optimistically about schools as offering emancipatory possibilities - in line with Freire (1970) and Giroux (1997). They envisioned more equitable forms of coexistence in the future, whereby all individuals would be 
empowered to make unique contributions to collective progress. Yet, their desired society could not be precisely defined; the world was inherently dynamic, open to constant redefinition through participation as evidenced in their more reflective attitude compared with custodial peers - a key difference in teacher identity and practice documented elsewhere (Wenren 2014).

The pedagogy described by teachers with humanistic orientation echoed principles of humanistic and adult education (Dewey 2008; Knowles 1977; Rogers and Horrocks 2010). They conceptualised knowledge as socially constructed, dependent upon context and experience, and organically structured. Learning outcomes were viewed as personal and holistic, not amenable to external 'objective' evaluation intended to grade/sort students. Classroom interactions were guided by principles of complementarity, democratic participation, critical dialogue, and collective ownership.

Lili and Yiannis (VP2) experienced ambivalence which took the form of cognitive dissonance (Lili) and/or inconsistent behaviour (Lili/Yiannis). Such ambivalence could be attributed to a poorly elaborated frame of reference - in the case of Lili, a largely unconscious humanistic worldview - coupled with anxiety over being accepted by their (controlling) custodial peers, as previous research demonstrates (Dewitt 1999; Wiley 2000).

Overall, the humanistic subculture, which constituted a minority, was overshadowed by the school's dominant custodialism. The one-dimensional perspective of custodial teachers, together with the Principal's centralised leadership, did not allow for deliberative democratic dialogue either with students or colleagues. Tensions between teachers and students, as well as between the two teacher ideologies, were often handled micro-politically. Humanists were often criticised for adopting a supposedly transactional approach vis-à-vis students. Unlike their custodial peers, they 
did not belong to well-bounded groups and worked in isolation, materialising their ideals within their classroom boundaries and under the limitations imposed by bureaucracy. In this oppressive climate, efforts at transformation were bound to be of limited impact, marginalised, or blocked, and at best, tokenistically endorsed as previous studies indicate (Czerniawski 2012; Lipman 1997; Robinson and Taylor 2013).

\section{Conclusion}

This study suggests that societal power relations are naturalised and embedded in custodial teachers' socio-cultural representations constituting a solid 'habitus' (Bourdieu and Passeron 1990, 45) through which they interpreted the world. It is, therefore, concluded that disengagement and tense relationships between staff and students in this Vocational Lyceum were largely rooted in this dominant worldview which regarded working-class/low-attaining students, and their socio-cultural capital, as innately inferior. Such determinism limited choice and voice, exerting symbolic violence upon students who often reacted as evidenced in previous research (Deuchar and Ellis 2013). Teachers’ uncritical view of knowledge and society disallowed dialogue and the identification of a meaningful purpose for vocational education. The latter was misinterpreted as mechanism for sorting inherently unequal individuals. This situation necessitated a change of perspective (no matter how difficult) to overcome the vicious cycle in which both teachers and students were trapped.

Humanists, instead, embraced students' socio-cultural capital. There is ground to support that a humanistic culture would be desirable, including previous research pointing to its association with enhanced student self-concept, self-actualisation, and academic optimism (Gilbert 2012; Hoy 2001). Promoting teachers with humanistic orientation to senior leadership positions would help create authentic learning school communities where democratic dialogue and transformative learning could thrive. Yet, 
it is uncertain whether this is possible in current custodial structures established at systemic level bound to select those who 'fit'.

Furthermore, professional development programmes should pay attention to raising sociological and political awareness among teachers, exposing deep-seated assumptions hidden in practices. This may contribute to a change of perspective or a change of 'habitus', allowing them to overcome their current ‘self-delusion’ (Giroux 1997, 14) of 'moral' or 'rational' practice. Such development would include deliberative discussions on substantive socio-political issues coupled with emancipatory action research, including, for example, spending time living close to students (Martin 2005).

Despite previous research supporting the need to strengthen epistemic disciplinary content in vocational education curricula (Wheelahan 2016), in Greece, despite the existence of such curricula, institutional and social hierarchies are still being perpetuated. Perhaps what is missing is the study of critical social theories which could help deconstruct and (subsequently) reconstruct custodial teachers' worldviews as embedded in their practice.

\section{Notes}

1. By 'officially' we mean 'as defined by educational legislation'.

2. Exceptions are laboratory assistants holding lower-level qualifications.

3. $66 \%$ of parents in Vocational Lyceums have completed lower-secondary education or less, compared with 33\% in General Lyceums (Pedagogical Institute 2008).

4. Occupation protests consist of students entering in, and occupying, a school for an extended period, impeding the conduct of classes.

5. Cultural capital refers to non-financial assets individuals possess which create for them differential chances of succeeding within existing societal structures and achieving upward social mobility (Bourdieu and Passeron 1990).

6. In Greece, external school evaluation was abolished in the 1980s. 


\section{References}

Abu Saad, I., and V. L. Hendrix. 1993. "Pupil Control Ideology in a Multicultural Society: Arab and Jewish Teachers in Israeli Elementary Schools.’’ Comparative Education Review 37 (1): 21-30.

Ballantine, J. H., and J. Z. Spade. 2015. Schools and Society: A Sociological Approach to Education. 5th ed. Thousand Oaks, CA: Sage.

Bas, G. 2011. “Teacher Student Control Ideology and Burnout: Their Correlation.”' Australian Journal of Teacher Education 36 (4): 84-94.

Beachum, F. D., A. M. Dentith, C. R. McCray, and T. M. Boyle. 2008.

“'Havens of Hope or the Killing Field: The Paradox of Leadership, Pedagogy, and Relationships in an Urban Middle School.’ Urban Education 43 (2): 189215.

Biesta, G. 2007. “'Why 'What Works’ Won’t Work: Evidence-Based Practice and the Democratic Deficit in Educational Research.’’ Educational Theory 57 (1): 1-22.

Blust, R. S., and D. J. Willower. 1979. “'Organizational Pressure, Personal Ideology and Teacher Pupil Control Behavior.’' Journal of Educational Administration 17 (1): 68-74.

Boone, S., and M. Van Houte. 2013. "In Search of the Mechanisms Conducive to Class Differentials in Educational Choice: A Mixed Method Research."' The Sociological Review 61: 549-572.

Bourdieu, P., and J. C. Passeron. 1990. Reproduction in Education, Society and Culture. 2nd ed. London: Sage.

Carrington, S., and J. Elkins. 2002. "Comparison of a Traditional and an Inclusive Secondary School Culture.’' Inclusive Education 6 (1): 1-16.

CEDEFOP. 2014. Vocational Education and Training in Greece: Short Description. Luxembourg: Publications Office of the European Union. Accessed June 2016. http://www.cedefop.europa.eu/EN/Files/4130_en.pdf

Czerniawski, G. 2012. “Repositioning Trust: A Challenge to Inauthentic Neoliberal Uses of Pupil Voice.’ Management in Education 26 (3): 130-139.

Deuchar, R., and J. Ellis. 2013. “' 'It’s Helped me with my Anger and I’m Realising Where I Go in Life': The Impact of a Scottish Youth Work / Schools Intervention on Young People’s Responses to Social Strain and Engagement 
with Anti-Social Behaviour and Gang Culture.’' Research in Post-Compulsory Education 18 (1-2), 98-114.

Dewey, J. 2008. Democracy and Education. Radford, VA: Wilder Publications.

Dewitt, P. 1999. “A Third Grade Teacher in a Technocratic School Asks a Dangerous Question: What is Learning?’' Interchange 30: 399-414.

Eichhorst, W., N. Rodríguez-Planas, R. Schmidl, and K. F. Zimmermann. 2015. “A Road Map to Vocational Education and Training in Industrialized Countries.’' Industrial \& Labor Relations Review 68 (2): 314-337.

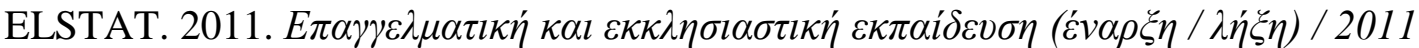
[Vocational and Ecclesiastical Education (Start / End) / 2011]. Accessed June 2016. http://www.statistics.gr/el/statistics/-/publication/SED25/2011

Fosnot, C. T. 2005. “Epilogue. Constructivism Revisited: Implications and Reflection.”' In Constructivism. Theory, Perspectives, and Practice. 2nd ed. Edited by C. Fosnot, 276-291. New York, NY: Teachers College Press.

Freire, P. 1970. Pedagogy of the Oppressed. New York, NY: Seabury Press.

Fullan, M. 2007. The New Meaning of Educational Change. 4th ed. New York, NY: Teachers' College Press and Routledge.

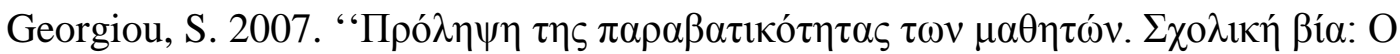

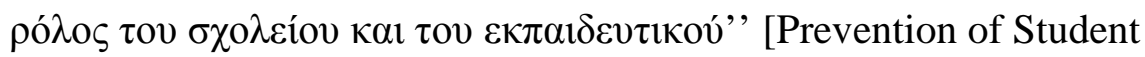
Delinquency. School Violence: The Role of the School and the Teacher]. Masters' thesis, Panteion University of Social and Political Sciences, Athens, Greece. Accessed June 2016. http://pandemos.panteion.gr/index.php?op=record\&pid=iid:709

Giddens, A. 1985. The Constitution of Society. Outline of the Theory of Structuration. Cambridge: Polity Press.

Gilbert, M. J. 2012. “The Relationship between Pupil Control Ideology and Academic Optimism.’’ PhD diss., Seton Hall University, South Orange, New Jersey. Accessed June 2016. http://scholarship.shu.edu/cgi/viewcontent.cgi?article=2789\&context=dissertatio $\underline{\mathrm{nS}}$

Giroux, H. 1997. Pedagogy and the Politics of Hope: Theory, Culture and Schooling. Oxford: Westview Press. 
Gordon, J., and J. A. Patterson. 2008. “' 'It’s What We’ve Always Been Doing.' Exploring Tensions between School Culture and Change.’' Journal of Educational Change 9 (1): 17-35.

Greenberg, J., H. Putman, and K. Walsh. 2014. Training our Future Teachers. Classroom Management. Washington, DC: National Council on Teacher Quality.

Grimaldi, E. 2012. “Neoliberalism and the Marginalisation of Social Justice: The Making of an Education Policy to Combat Social Exclusion.’' International Journal of Inclusive Education 16 (11): 1131-1154.

Grollmann, P. 2008. "The Quality of Vocational Teachers: Teacher Education, Institutional Roles and Professional Reality.’' European Educational Research Journal 7 (4): 535-547.

Hermans, R., J. V. Braak, and H. Van Keer. 2008. “'Development of the Beliefs about Primary Education Scale: Distinguishing a Developmental and Transmissive Dimension.” Teaching and Teacher Education 24 (1): 127 - 139.

Herr, K., and G. Anderson. 2003. "Violent Youth or Violent Schools? A Critical Incident Analysis of Symbolic Violence.’' International Journal of Leadership in Education: Theory and Practice 6 (4): 415-433.

Hillmert, S., and M. Jacob. 2003. “'Social Inequality in Higher Education: Is Vocational Training a Pathway Leading to or Away from University?’’ European Sociological Review 19 (3): 319-334.

Hoy, W. K. 2001. “The Pupil Control Studies: A Historical, Theoretical and Empirical Analysis.”' Journal of Educational Administration 39 (5): 424-441.

Hoy, W. K., and C. G. Miskel 2013. Educational Administration: Theory, Research, and Practice. 9th ed. New York, NY: McGraw Hill.

Jackson, M., R. Erikson, J. Goldthorpe, and M. Yaish. 2007. “Primary and Secondary Effects in Class Differentials in Educational Attainment.”' Acta Sociologica 50 (3): 211-229.

Jaeger, M. M. 2009. “Equal Access but Unequal Outcomes: Cultural Capital and Educational Choices in a Meritocratic Society.’' Social Forces 87 (4): 19431972.

Johnstone, B. 2008. Discourse Analysis. 2nd ed. Oxford: Blackwell. 
Karakus, M., and A. C. Savas. 2012. “The Effects of Parental Involvement, Trust in Parents, Trust in Students and Pupil Control Ideology on Conflict Management Strategies of Early Childhood Teachers.’’ Educational Sciences: Theory and Practice 12 (4): 2977-2985.

Kelly, S., and H. Prince. 2009. “'Vocational Education: A Clean Slate for Disengaged Students?’’ Social Science Research 38 (4): 810-825.

Kloosterman, R., S. Ruiter, P. M. de Graaf, and G. Kraaykamp. 2009. “'Parental Education, Children's Performance and the Transition to Higher Secondary Education: Trends in Primary and Secondary Effects over Five Dutch School Cohorts (1965-99).’’ The British Journal of Sociology 60 (2): 377-398.

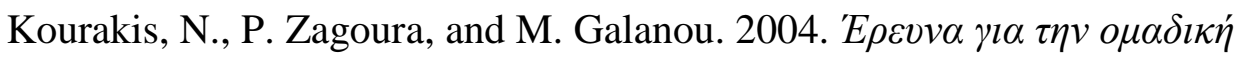
$\pi \alpha \rho \alpha \beta \alpha \tau \iota \kappa o ́ \tau \eta \tau \alpha \mu \alpha \theta \eta \tau \omega ́ v ~ \lambda v \kappa \varepsilon i ́ o v ~ \sigma \varepsilon ~ \sigma \chi o \lambda \varepsilon i ́ \alpha ~ \tau \omega v ~ A \theta \eta v \omega ́ v$ [Research on Students’ Group Delinquency in Upper-Secondary Schools of Athens]. Athens: Laboratory of Penal and Criminal Research, University of Athens. Accessed June 2016. http://old.law.uoa.gr/crime-research/omparavatikotita.pdf

Knowles, M. 1977. “'Adult Learning Processes: Pedagogy and Andragogy.” Religious Education 72 (2): 202-211.

Lambert, L. 2009. “'Constructivist Leadership.” In The Essentials of School Leadership, edited by B. Davies, 112-132. London: Sage.

Lawrence, A. 1986. Schooling for Social Order: Democracy, Equality and Social Mobility in Education. Sociology of the School. Victoria: Deakin University Press.

Lipman, P. 1997. “'Restructuring in Context: A Case Study of Teacher Participation and the Dynamics of Ideology, Race, and Power.’' American Educational Research Journal 34 (1): 3-37.

Littledyke, M., and E. Manolas, E. 2010. “'Ideology, Epistemology, and Pedagogy: Barriers and Drivers to Education for Sustainability in Science Education.’’ Journal of Baltic Science Education 9 (4): 285-302.

Lotto, L. S. 1988. “What about Vocational Education: A Review of the Evidence.” Educational Policy 2 (3): 265-285.

Lunenburg, F. C., and S. A. Mankowsky. 2000. “Bureaucracy and Pupil Control Orientation and Behavior in Urban Secondary Schools.’’ Paper presented at the Annual Meeting of the American Educational Research Association, New 
Orleans, LA, April 24-28. Accessed June 2016.

http://eric.ed.gov/?id=ED445154

Lyons, E., and A. Coyle, A. 2016. Analysing Qualitative Data in Psychology. $2^{\text {nd }}$ ed. London: Sage.

Martin, R. J. 2005. “An American Dilemma: Using Action Research to Frame Social Class as an Issue of Social Justice in Teacher Education Courses.”' Teacher Education Quarterly 32 (2): 5-22.

McCulloch, G. 2005. “Curriculum Reform, Educational Change and School Improvement."' In. The Practice and Theory of School Improvement. International Handbook of Educational Change, edited by D. Hopkins, 169-181. Dordrecht: Springer.

McGarr, O., and O. McCormack. 2014. ' Reflecting to Conform? Exploring Irish Student Teachers’ Discourse in Reflective Practice.’ The Journal of Educational Research 107 4: 267-280.

McNeil, L. 1988. Contradictions of Control: School Structure and School Knowledge. New York: Routledge.

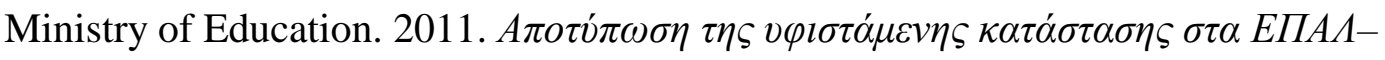

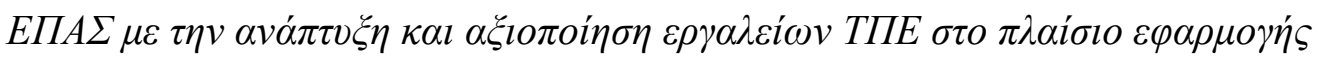

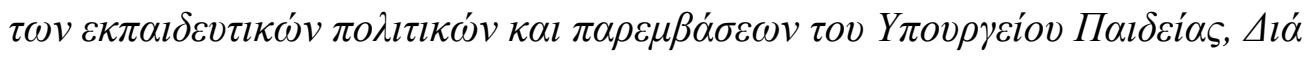

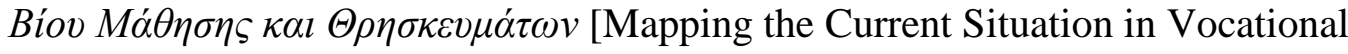
and Technical Lyceums with the Use of ICT Technology in the Context of Policies and Interventions Implemented by the Ministry of Education, Lifelong Learning and the Religions]. Accessed June 2016. http://www.sch.gr/96announces/1966-2011-05-23-12-32-22

Morris, E. W. 2008. “' 'Rednecks,' 'Rutters,' and 'Rithmetic: Social Class, Masculinity, and Schooling in a Rural Context.”' Gender \& Society 22 (6): 728-751.

Murray, P., and J. Polesel. 2013. “ A Comparative Exploration of Learning Pathways and Transition Systems in Denmark and Australia.'” European Journal of Education 48 (2): 233-246.

Ngidi, D. P. 2012. “'Academic Optimism: An Individual Teacher Belief.’’ Educational Studies 38 (2): 139-150. 
Packard, J. S. 1988. “'The Pupil Control Studies.’’ In Handbook of Research on Educational Administration, edited by N. J. Boyan, 185-207. New York: Longman.

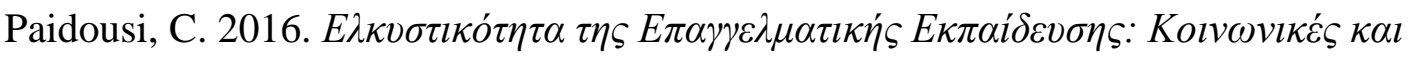
$\varepsilon \dot{\mu} \mu \nu \nu \lambda \varepsilon \varsigma \delta \imath \alpha \sigma \tau \dot{\alpha} \sigma \varepsilon \imath \varsigma$ [Attractiveness of Vocational Education: Social and Gender Dimensions]. Athens: EIEAD. Accessed June 2016. http://www.eiead.gr/index.php?option=com_content\&view=article\&id=162\&Ite $\underline{\text { mid=179\&lang }=\mathrm{el}}$

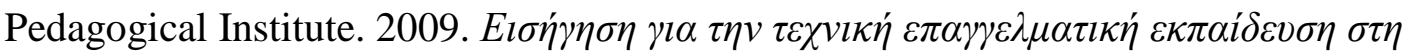
$\delta \varepsilon v \tau \varepsilon \rho \circ \beta \alpha \dot{\theta} \theta \mu \imath \alpha \varepsilon \kappa \pi \alpha i \delta \varepsilon v \sigma \eta$ [Recommendations for Technical Vocational Education in Secondary Education]. Accessed June 2016. http://statathens.aueb.gr/ jpan/texniki-epaggelmatiki-ekpaideusi-pi-18jn09.pdf

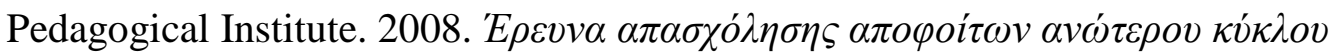

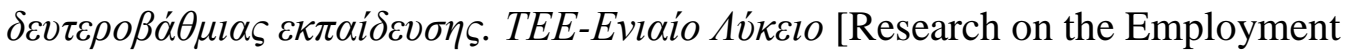
of Graduates of the Upper Cycle of Secondary Education. VET-General Lyceum]. Accessed June 2016. http://kesyp.chal.sch.gr/files/enimer/erevnes_A1.pdf

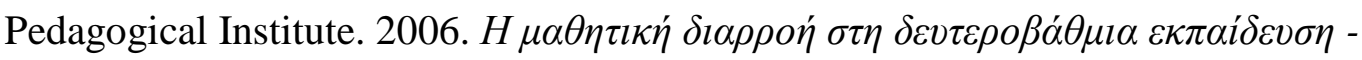

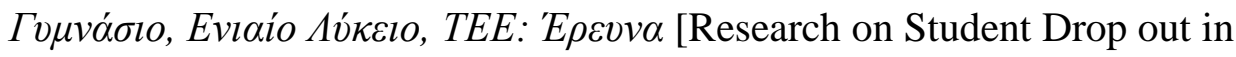
Secondary Education - Gymnasium, General Lyceum, VET: Research]. Accessed June 2016. http://www.epimelitesanilikon.gr/pdf/DIARROH.pdf Polesel, J. 2010. "'Vocational Education and Training (VET) and Young People: The Pathway to the Poor?' Education + Training 52 (5): 415-426.

Rassool, N., and L. Morley. 2000. "'School Effectiveness and the Displacement of Equity Discourses in Education.” Race Ethnicity and Education 3 (3): 237-258. Rideout, G., and S. Windle. 2013. “'Researcher Identified and Emergent Predictors of Pupil Control Ideologies: A Canadian Beginning Teacher Perspective.’' Teacher Development: An International Journal of Teachers' Professional Development 17 (4): 478-498.

Robinson, C., and C. Taylor. 2013. “'Student Voice as a Contested Practice: Power and Participation in Two Student Voice Projects.’’ Improving Schools 16 (1): 32-46. Rogers, A., and N. Horrocks. 2010. Teaching Adults. 4th ed. Maidenhead: Open University Press. 
Schein, E. H. 2010. Organizational Culture and Leadership. 4th ed. San Francisco, CA: Jossey-Bass.

Silvernail, D. L. 1992. “The Educational Philosophies of Secondary School Teachers.” The High School Journal 75 (3): 162-167.

Skills Commission. 2010. Teacher Training in Vocational Education: A Report by the Skills Commission. Accessed June 2016.

http://www.policyconnect.org.uk/sc/sites/site_sc/files/report/348/fieldreportdow nload/teachertraininginvocationaleducation1.pdf

Small, M. L. 2011. “How to Conduct a Mixed Methods Study: Recent Trends in a Rapidly Growing Literature.’’ Annual Review of Sociology 37: 57-86.

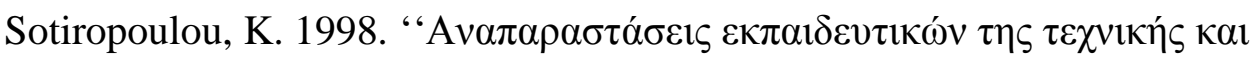

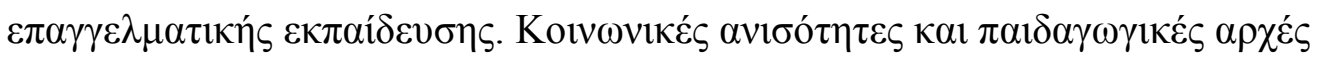

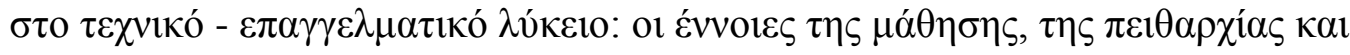
$\tau \eta \varsigma \pi \rho о \sigma \alpha \rho \mu о \gamma \eta ́ \varsigma$ '” [Vocational Teachers’ Representations. Social Inequalities and Pedagogical Principles in the Vocational-Technical Lyceum: The Notions of Learning, Discipline, and Adjustment]. PhD diss., National University of Athens, Greece. Accessed June 2016. http://thesis.ekt.gr/thesisBookReader/id/12262\#page/1/mode/2up

Stoll, L., R. Bolam, A. McMahon, M. Wallace, and S. Thomas. 2006. “Professional Learning Communities: A Review of the Literature.’ Journal of Educational Change 7 (4): 221-258.

Thornberg, R. 2010. “'School Democratic Meetings: Pupil Control Discourse in Disguise.” Teaching and Teacher Education 26 (4): 924-932.

van der Kooij, J. C., D. J. de Ruyter, and S. Miedema. 2013. “"Worldview’: The Meaning of the Concept and the Impact on Religious Education.’’ Religious Education 108 (2): 210-228.

Van Houtte, M. 2005. “'Climate or Culture? A Plea for Conceptual Clarity in School Effectiveness Research.’’ School Effectiveness and School Improvement 16 (1): 71-89.

Van Houtte, M. 2004. “Tracking Effects on School Achievement: A Quantitative Explanation in Terms of the Academic Culture of School Staff.’' American Journal of Education 110 (4): 354-388. 
Van Houtte, M., J. Demanet, and P. A. J. Stevens. 2012. "'Self-Esteem of Academic and Vocational Students: Does Within-School Tracking Sharpen the Difference?’’ Acta Sociologica 55 (1): 73-89.

Van Houtte, M., and P. A. J. Stevens. 2010. “The Culture of Futility and its Impact on Study Culture in Technical/Vocational Schools in Belgium.’' Oxford Review of Education 36 (1): 23-43.

Wenren, X. 2014. “The Construction of the Teacher’s Authority in Pedagogic Discourse.’' English Language Teaching 7 (6): 96-108.

Wheelahan, L. 2016. “' 'College for All’ in Anglophone Countries - Meritocracy or Social Inequality? An Australian Example.’' Research in Post-Compulsory Education 21 (1-2): 33-48.

Wiley, C. 2000. “A Synthesis of Research on the Causes, Effects, and Reduction Strategies of Teacher Stress.’’ Journal of Instructional Psychology 27 (2): 8087.

Willower, D. J., T. Eidell, and W. Hoy. 1967. The School and Pupil Control Ideology. Serial No. 24. Pennsylvania State University Monographs.

Willower, D. J., and R. G. Jones. 1963. “When 'Pupil Control’: Becomes an Institutional Theme.’ The Phi Delta Kappan 45 (2): 107-109.

Woolley, S. L., W. J. J. Benjamin, and A. W. Woolley. 2004. “'Construct Validity of a Self-Report Measure of Teacher Beliefs Related to Constructivist and Traditional Approaches to Teaching and Learning."' Educational and Psychological Measurement 64 (2): 319-331.

Wrigley, T. 2008. “'School Improvement in a Neo-Liberal World.” Journal of Educational Administration and History 40 (2): 129-148.

Yin, K. R. 2009. Case Study Research: Design and Methods. 4th ed. Los Angeles: Sage. 
Table 1. Characteristics of interview participants and those providing written narratives.

\begin{tabular}{|c|c|c|c|c|c|c|c|c|}
\hline Pseudonyms & Gender & Age & $\begin{array}{l}\text { Educational } \\
\text { experience }\end{array}$ & $\begin{array}{l}\text { Years in } \\
\text { school }\end{array}$ & Subject & PCI & Interview & $\begin{array}{l}\text { Written } \\
\text { narrative }\end{array}$ \\
\hline $\begin{array}{l}\text { Periklis } \\
\text { (Principal) }\end{array}$ & Male & 48 & 21 & 16 & Vocational & 69 & Yes & - \\
\hline $\begin{array}{l}\text { Christos } \\
\text { (V. Principal 1) }\end{array}$ & Male & 47 & 16 & 10 & Vocational & 54 & Yes & - \\
\hline $\begin{array}{l}\text { Yiannis } \\
\text { (V. Principal 2) }\end{array}$ & Male & 50 & 15 & 3 & General & 57 & Yes & - \\
\hline Alexis & Male & 50 & 10 & 5 & Vocational & 62 & Yes & - \\
\hline Antreas & Male & 42 & 13 & 8 & Vocational & 69 & Yes & - \\
\hline Lili & Female & 32 & 9 & 2 & Vocational & 55 & Yes & Yes \\
\hline Lefteris & Male & 42 & 15 & 10 & Vocational & 62 & Yes & - \\
\hline Filippos & Male & 39 & 8 & 2 & General & 47 & Yes & - \\
\hline Stavros & Male & 48 & 21 & 16 & Vocational & 67 & Yes & - \\
\hline Melpo & Female & 52 & 31 & 1 & General & 64 & Yes & - \\
\hline Thomae & Female & 37 & 12 & 2 & General & 62 & Yes & - \\
\hline Orpheas & Male & 34 & 8 & 1 & General & 75 & Yes & Yes \\
\hline Simos & Male & 50 & 20 & 8 & Vocational & 58 & - & Yes \\
\hline
\end{tabular}


Table 2. Teachers' Pupil Control Ideology (PCI): Descriptive statistics.

\begin{tabular}{ll}
\hline & PCI $^{\mathbf{a}}$ \\
\hline Mean & 63.3 \\
Standard deviation (SD) & 8.9 \\
Median & 64 \\
Minimum & 43 \\
Maximum & 82 \\
\hline
\end{tabular}

a Scores could range from 20 to 100. Higher scores denote a more custodial 